ON THE RECORD

c(Please post my seeds in a plain, unmarked envelope with no indication of contents to ensure smooth arrival."》

Horticulturalist Susan Davies gives instructions for delivering illegal rhododendron seeds to her New

Zealand home. She was fined US $\$ 3,200$ for violating the nation's biosecurity act.

\section{"(Actually, King Tut has} been flattered by the embalmers' work.")

Mummy expert Eduard Egarter Vigl reports on the state of the king's mummified penis, which was recently found in the sand around his body.

Sources: Manawatu Standard, The Times

\section{SCORECARD}

Taxis

The Pentagon launches a competition to build an autonomous vehicle that can navigate city streets.

$\checkmark$ Jellyfish German scientists show that jellyfish perform one of the fastest cellular processes in nature: they eject their stinging cells in just 700 nanoseconds.

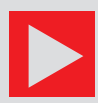
Contraceptives The Vatican is reconsidering its rules on condom use - but any lifting of the ban would apply only to married couples with HIV.

\section{OVERHYPED}

\section{Coma drama}

Hollywood scriptwriters love putting characters into comas, but irate neurologists say they are fudging the facts. The most common error in $\mathbf{3 0}$ movies studied was the suggestion that coma patients keep their toned bodies and perfect tans over a period of years. The cinema also glosses over details of comatose life such as incontinence, feeding tubes and respirators. Most significantly, the authors point out, there is no evidence that patients waking from a coma immediately seek revenge.

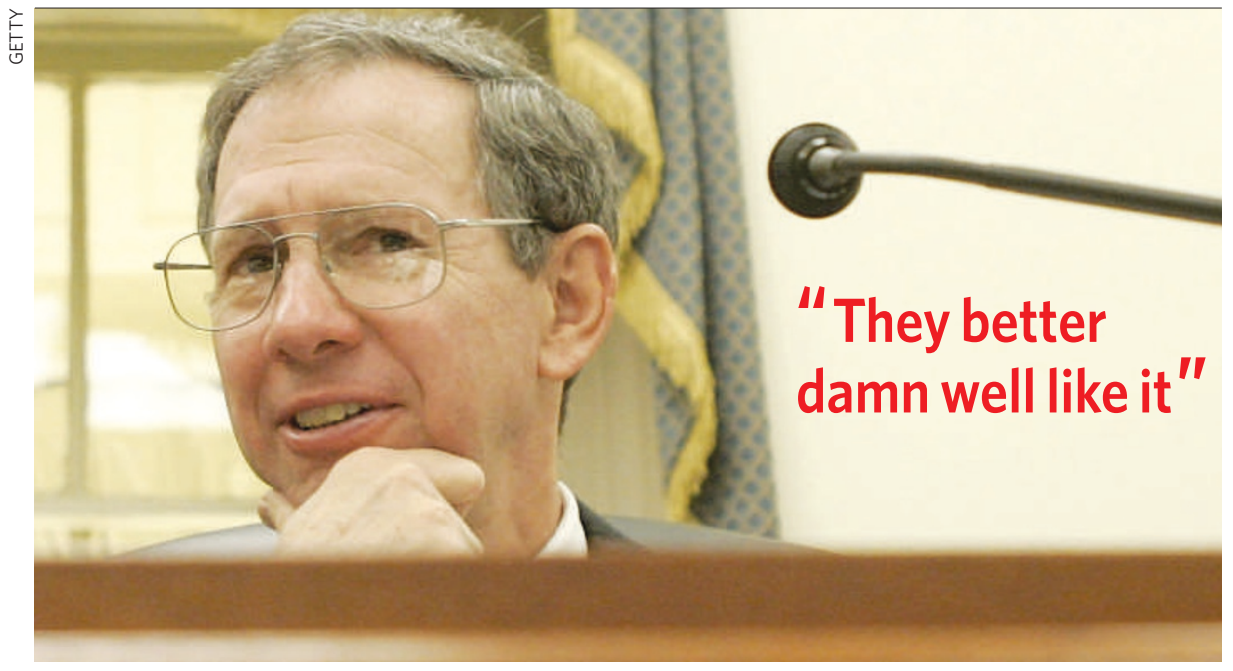

\title{
Outspoken: Mike Griffin on the NASA budget
}

NASA head Mike Griffin was blunter than usual last week, as he defended his scaling back of the agency's science programme. Space scientists have responded angrily to the cutbacks (see Nature $439,768-769 ; 2006$ ), but Griffin insisted to two key advisory groups - the Space Studies Board and the science subcommittee of the NASA Advisory Council - that the science programme is still healthy. He made it clear, however, that the White House's plan to send astronauts to the Moon and Mars takes priority over increased science funding. And although he is willing to rethink some specifics, he reminded scientists "to be respectful of the political and budgetary constraints we face".

\section{Griffin's stance on...}

Whether budget cuts might be reversed

We're willing to reconsider, but

reconsideration should be based on community input, not the loudest voice, the longest e-mail or who can use the most capitals.

The outcry over cutting research grants The community doesn't care if we fly missions; they want money for universities. I find that, to be honest with you, appalling.

\section{A law requiring NASA to try to rescue the Hubble telescope - even though such a mission would take hundreds of millions of dollars from other science projects I hope the astronomy community likes the decision they lobbied for. They better damn well like it, because they got it.}

Cutbacks to life-sciences research aboard the International Space Station

What is the point of funding life-sciences research when I can't put people into space? I need the budget I have to recreate abilities that we once had to fly [beyond Earth orbit], that we don't have any more. It's a sequencing problem.

\section{Deep cuts to NASA astrobiology}

I did think astrobiology was less important than traditional space science. It had less intrinsic subject matter to it, and was less advanced. If the community rises up and says it should be funded, we'll rethink it.

\section{Opportunities for science on the Moon} I have to draw the line when people say "I'm not interested in the Moon. I would rather put the money into studying the physics of the tropopause."

OK, great. Glad you have an opinion; everybody gets one. But the people who run the country have decided that we are in fact going to the Moon. It's a question of what scientists would like to do with that.

\section{The importance of finishing the International Space Station}

As administrator, I inherit a situation not of my liking. But other nations have spent a very significant part of their own discretionary space funding supporting our agenda. They built their hardware, and they want to see it flown. I want us to honour this commitment. Tony Reichhardt 